\title{
Determination of Some Heavy Metals in Groundwater and Table Water in Tudun Murtala, Nassarawa Local Government Area, Kano-Nigeria
}

\author{
${ }^{1}$ Nasiru, S., ${ }^{2}$ Aliyu, A., 'Garba, M.H., 'Dambazau, S. M., \\ ${ }^{1}$ Nuraddeen, A., ${ }^{2}$ Abba Babandi, ${ }^{2}$ Murtala Ya'u \\ ${ }^{1}$ Department of Biochemistry, Faculty of Science, \\ Federal University Dutse, \\ Jigawa, Nigeria. \\ 2 Department of Biochemistry, \\ Faculty of Basic Medical Science, \\ Bayero University, Kano, Nigeria.
}

Email: salihu_nasiru@yahoo.com

\begin{abstract}
This study determine the level of heavy metals $(\mathrm{Pb}, \mathrm{Cd}, \mathrm{Cr}, \mathrm{Zn}, \mathrm{Fe})$ in water samples obtained from different sources (well water, borehole water and table water) in Tudun Murala, Nassarawa local government area, Kano state. The concentrations of heavy metals in the water samples were determined using flame Atomic Absorption spectrometer. Results showed that the concentration of $\mathrm{Pb}, \mathrm{Cd}, \mathrm{Cr}$ and $\mathrm{Fe}$ in water samples were within the range: 0.295- 0.579, 0.471-0.529, 0.550- 1.000, $0.3636-0.4545 \mathrm{mg} / \mathrm{l}$ respectively, which were above the permissible limits set by WHO. Whereas the concentration of $\mathrm{Zn}(0.0814-0.173)$ was within the limit set. The elevated concentration of heavy metals could be linked to environmental factors and industrial pollution in the area.
\end{abstract}

Keywords: Heavy metals, AAS, Environmental factors, industrial pollution

\section{INTRODUCTION}

Water is one of the most important ingredient essential for the well-being of people, it makes up about $60 \%$ of the weight in men and $55 \%$ of weight in women (Miller and Thomas, 2006). It is essential in many processes taking place within the body such as transport of nutrient within the body, breakdown of foods, waste elimination, body temperature regulation and for the normal metabolism of human body, the essential metals must be taken up from water, food or sediment (Canh and Ahn, 2013).

Drinking water is found in variety of sources which include groundwater, streams, rivers, water supply network, and also other sources. Considering the fact that most natural water sources are from the ground, a tendency of contamination is high, either from faecal contamination, microbial pathogens or dissolved metals. This to a large extent affects drinking water availability and also predispose individuals to water borne diseases. In 2006, waterborne diseases were estimated to cause 1.8 million deaths each year while about 1.1 billion people lacked proper drinking water (U.S. Centers for Disease Control and Prevention, 2006). Among these water contaminants, metals were found to cause diverse 
negative effects on health. The metals found in water are heavy metals. As trace amount, some heavy metals (such as copper, iron, chromium and nickel) are essential metals since they play an important role in biological systems, whereas some (like cadmium and lead) are non-essential metals, as they are toxic, even in trace amount (Farnandes et al., 2008).

These elements (metals) find their way into water supplies as a result of inadequate treatment of disposed waste and industrial discharges (Singnh and Mosley, 2003). The discharge of toxic heavy metals is a serious pollution problem affecting water quality especially in wet lands and other water masses due to their toxicity and bioaccumulative effect, creating a direct hazard to human health (Ogoyi et al., 2011). These metals disturb growth, development, reduce hemoglobin, create cancer, damage the body organs and the nervous system, and in extreme cases death of living organism (W.H.O, 2011).

As of 1997, Gulson et al., stated that maternal bone lead stores are mobilized at an accelerated rate during pregnancy and lactation and are associated with decrements in birth weight, growth rate, and mental development. Schwartz et al., (2001) pointed out that linked blood lead levels in the range of 7-40 mg/dl are linked with evidence of toxicity in adults, such as neurobehavioral decrements. Prenatal $\mathrm{Cd}$ exposure may impair postnatal $\mathrm{T}$ cell production and response to immunization (Hanson et al., 2012), as well as dysregulated thymocyte development (Hanson et al., 2010). Post-natal Cd exposures induce cell cycle arrest and apoptosis in splenocytes (Chatterjee et al., 2009). Cr (III) and any of its derived related species could attack DNA, proteins, and membrane lipids, thereby disrupting cellular integrity and functions (De Mattia, et al., 2004). Fe, if ingested excessively cause wide arrays of effect, although zinc is an essential requirement for good health, excess zinc can be harmful. Excessive absorption of zinc suppresses copper and iron absorption, Levels of 100$300 \mathrm{mg}$ may interfere with the utilization of copper and iron or adversely affect cholesterol (Fosmire, 1990).

Heavy metals contamination is particularly on the increase in the urban areas where industrial as well as occupational activities are largely concentrated. However, in many cities of developing countries like Nigeria, reliable data pertaining to the presence of heavy metal contaminants of a specified area is mostly unavailable; this is also applicable to most of the contaminated areas in Kano metropolis. This study is aimed at determining some heavy metals in groundwater and table water samples in Tudun Murtala, Nassarawa local government area, Kano state.

\section{MATERIALS AND METHOD}

Background of study area

Kano state is located in the northern part of Nigeria,it is in the sahelian geographical region,south of the sahara. It is the second largest city in Nigeria after Lagos and the most populous state in the whole country with about 9,383,682 people (census 2006). It is bounded by the latitude $12^{\circ} 00^{1} 0.43^{\text {II }} \mathrm{N}$ and longitude $8^{\circ} 31^{\text {I }} 0.19^{\text {II }} \mathrm{E}$. Nassarawa is one of the local governments of Kano, It has an area of $34 \mathrm{~km}^{2}$ and its densely populated. Tudun Murtala is a ward in Nassarawa local government with various industries and roadside occupational sites, mainly mechanic workshops and heavy duty servicing sites. This area was selected for this study due to its density of industries and high levels of pollution.

Sample collection 
The samples collected were groundwater and table water. A total of thirty four water samples were collected; twenty four samples from groundwater and ten from table water sold in the area. The samples of groundwater were strategically collected from Nassarawa local government, Kano state from the houses situated in Tudun Murtala and from a distance of 250m away from the Tudun Murtala (Kwanar jaba), and then bore hole water. Samples from these strategic locations were collected using $1 \mathrm{dm}^{3}$ pet bottle for the analysis.

$1 \mathrm{dm}^{3}$ liter flasks were previously washed with water, dilute $\mathrm{HNO}_{3}$ and rinsed severally with distilled water. At each sampling site, the sample bottles were labeled correctly, rinsed twice with the water before collection. Information such as date of collection, location, serial identifications about each sample collected was recorded on labels pasted on each container.

\section{Sample analysis}

In determination of the level of metal in water, the first objective is to obtain the metal in concentrated form, which is separated from as many sources of interference as possible and this is usually carried out using the process called digestion. $100 \mathrm{~cm}^{3}$ of each of the representative water samples were transferred into beakers and $5 \mathrm{~cm}^{3}$ of concentrated $\mathrm{HNO}_{3}$ were added. The beaker with the content was placed on a hot plate. The samples were boiled slowly and then evaporated on the hot plate to the lowest volume of $20 \mathrm{~cm}^{3}$. The beakers were allowed to cool and another $5 \mathrm{~cm}^{3}$ of concentrated $\mathrm{HNO}_{3}$ was added. The beakers were covered with watch glass and returned to the hot plate. Heating was continued and $\mathrm{HNO}_{3}$ was added as necessary until the solution appeared light coloured and cleared (i.e. digestion was complete). The watch glass and beaker walls were washed with distilled water and filtered to remove insoluble materials that could clog the atomizer. The filtrates were transferred to $100 \mathrm{~cm}^{3}$ volumetric flasks and diluted to the mark with distilled water. These solutions were then used for the analysis (i.e. obtaining the concentration of each metal). (Akan et al., 2007).

\section{Statistical Analysis}

Statistical analyses were performed using SPSS statistical package (version 16; SPSS, Chicago, IL). The one-way analysis of variance (ANOVA) was used to verify significant differences in trace element concentrations among the water samples. The trace element concentrations were expressed as microgram per litre $(\mathrm{w} / \mathrm{v})$. Values were given in means \pm standard deviation.

\section{RESULTS AND DISCUSSION}

The concentration of heavy metals $(\mathrm{mg} / \mathrm{l})$ from well water from different houses (A-J), located in Tudun Murtala are presented in table 1

Table 1. Concentrations of metals (mg/l) in well water at Tudun Murtala

\begin{tabular}{lllllll}
\hline $\mathrm{S} / \mathrm{N}$ & SAMPLES & $\mathrm{Pb}$ & $\mathrm{Cd}$ & $\mathrm{Cr}$ & $\mathrm{Zn}$ & $\mathrm{Fe}$ \\
\hline 1 & $\mathrm{~A}$ & 0.0952 & 0.4286 & 0.25 & 0.0203 & 0.0590 \\
2 & $\mathrm{~B}$ & 0.6190 & 0.5714 & 0.25 & 0.2542 & 0.5454 \\
3 & $\mathrm{C}$ & 0.4762 & 0.7857 & 0.25 & 0.1582 & 0.7727 \\
4 & $\mathrm{D}$ & 1.9048 & 0.6429 & 1.25 & 0.1977 & 0.3181 \\
5 & $\mathrm{E}$ & 0.3333 & 0.50 & 0.50 & 0.1299 & 0.2727 \\
6 & $\mathrm{~F}$ & 0.0714 & 0.4285 & 0.75 & 0.3898 & 0.5454 \\
7 & $\mathrm{G}$ & 0.4761 & 0.7143 & 0.50 & 0.2203 & N.D \\
8 & $\mathrm{H}$ & 0.7143 & 0.1429 & 0.25 & 0.1073 & 0.5909 \\
9 & $\mathrm{I}$ & 0.5238 & 0.7857 & 1 & 0.1977 & 0.6363 \\
10 & $\mathrm{~J}$ & 0.5714 & 0.2857 & 0.5 & 0.0508 & 0.3636 \\
\hline
\end{tabular}

A-J: codes for houses in Tudun Murtala 
Table 2: Concentrations of metals $(\mathrm{mg} / \mathrm{l})$ in borehole water at Tudun Murtala

\begin{tabular}{lllllll}
\hline $\mathrm{S} / \mathrm{N}$ & Water samples & $\mathrm{Pb}$ & $\mathrm{Cd}$ & $\mathrm{Cr}$ & $\mathrm{Zn}$ & $\mathrm{Fe}$ \\
\hline 11 & $\mathrm{~A} 1$ & 0.7619 & 0.4286 & 0.7500 & 0.0847 & 0.2727 \\
12 & $\mathrm{~B} 1$ & 0.3333 & 0.8571 & 0.5000 & 0.0158 & 0.5454 \\
13 & $\mathrm{C} 1$ & 0.5238 & 0.4286 & 0.5000 & 0.1243 & 0.5454 \\
14 & $\mathrm{D} 1$ & 0.2143 & 1.0000 & 0.0090 & 0.0909 \\
15 & $\mathrm{E} 1$ & 1.5000 & 1.2500 & 0.2034 & 0.5000 \\
16 & $\mathrm{~F} 1$ & 0.6190 & 0.2143 & 1.0000 & 0.1638 & 0.5000 \\
17 & $\mathrm{G} 1$ & 0.4762 & 0.5714 & 0.5000 & 0.0960 & N.D \\
18 & $\mathrm{H} 1$ & 0.4762 & 1.0000 & 0.7500 & 0.1808 & 0.5000 \\
\hline
\end{tabular}

From table 1, A-J are well water samples of which their concentrations of heavy metals are high, with $\mathrm{Pb}$ concentration ranging from 0.0714 to $1.9048 \mathrm{mg} / \mathrm{l}$, which shows a higher value compared to the borehole water within the same area in table $2 \mathrm{~Pb}$ having a concentration ranging from 0.2381 to 0.7619 ), and both having higher values than $0.01 \mathrm{mg} / 1 \mathrm{WHO}(2008)$ permissible limits for drinking water. This level might be due to the use and processing of lead materials in various forms such as leaded gasoline, smelting of lead and its combustion, battery recycling, lead based painting, lead containing pipes, grids and pigments. It might also be due to refuse dumped in the area containing lead, and because of lead's nonbiodegradable nature, it tends to accumulate in the environment, and because lead is absorbed through ingestion by food, water or inhalation it will bioaccumulate and exerts its toxicity by causing renal impairment or neurobehavioural decrements (Schwartz et al., 2001). Cd from well water samples (0.1429 to $0.7857 \mathrm{mg} / \mathrm{l})$ has lower concentrations as compared to the borehole water's $\mathrm{Cd}$ concentrations $(0.2143$ to $1.50 \mathrm{mg} / \mathrm{l})$, but both samples have a skyrocketed value as compared to $0.003 \mathrm{mg} / 1 \mathrm{WHO}$ (2008) permissible limits. This limit tends to be more violated in borehole water. This may be due to soil composition and environmental pollution or due to the application of biosolids or manures in the environment, it might also be linked to various air borne sources of metals such as emission of gas or vapour streams in the study area. As such the residents of this area are at unbearable risk of cadmium toxicity and might develop high risk of impaired vitamin D metabolism in kidney, causing kidney damage, osteomalacia and/or osteoporosis (Nordberg, 2007).

Cr concentrations from well water samples $(0.25$ to $1.00 \mathrm{mg} / \mathrm{l})$ also had lower concentrations as compared to the bore hole water samples $(0.5$ to $1.25 \mathrm{mg} / \mathrm{l})$, both also have higher values as compared to $0.05 \mathrm{mg} / 1$ WHO (2008) permissible limits. This values are highly elevated and risk of toxicity is high. Cr exist naturally on rocks and sands and it might contaminate water due to weathering and erosion of soils, alternatively it might be due to corrosion of chromium discharge from steel and pulp mills, or erosion of natural deposits. This toxicity might lead to increased risk of developing lung cancer and may also result in asthma and damage to the nasal epithelia and skin (Federal Register 2006). $\mathrm{Cr}$ can also lead to production of hydrogen peroxide $\left(\mathrm{H}_{2} \mathrm{O}_{2}\right)$, glutathione $(\mathrm{GSH})$ reductase, ascorbic acid, and GSH to produce reactive intermediates, including $\mathrm{Cr}(\mathrm{V}), \mathrm{Cr}(\mathrm{IV})$, thiylradicals, hydroxyl radicals, and ultimately, $\mathrm{Cr}(\mathrm{III})$ in which any of these species could attack DNA, proteins, and membranelipids, thereby disrupting cellular integrity and functions (De Mattia, et al., 2004).

Zn concentrations however, even though higher in well water, is within the permissible limit set. The level of $\mathrm{Zn}$ in the samples indicate that its toxicity will not be exerted as the permissible limits of WHO (2008) is set at $3.00 \mathrm{mg} / \mathrm{dm}^{3}$. Fe concentration fluctuates with a 
slight increase to the permissible limits of WHO (2008) set at $0.3 \mathrm{mg} / \mathrm{dl}$. If this level is not controlled toxicity might be inevitable and will lead to damaged cells in the heart, liver and elsewhere, which can cause significant adverse effects, including coma, metabolic acidosis, shock, liver failure, coagulopathy, adult respiratory distress syndrome, long term organ damage, and even death (Cheney et al., 1995).

Table 3: Concentrations (mg/l) of metals in well water at Kwanar Jaba

\begin{tabular}{lllllll}
\hline $\mathrm{S} / \mathrm{N}$ & Water samples & $\mathrm{Pb}$ & $\mathrm{Cd}$ & $\mathrm{Cr}$ & $\mathrm{Zn}$ & $\mathrm{Fe}$ \\
\hline 1 & $\mathrm{~A} 2$ & 0.4286 & 0.3571 & 1.00 & 0.0904 & 0.2270 \\
2 & $\mathrm{~B} 2$ & 0.1429 & 0.71429 & 0.50 & 0.1977 & N.D \\
3 & $\mathrm{C} 2$ & 0.0952 & 0.3571 & 0.50 & 0.0678 & N.D \\
4 & $\mathrm{D} 2$ & 0.6667 & 0.4286 & 1.25 & 0.0791 & 0.5454 \\
5 & $\mathrm{E} 2$ & 0.4762 & 0.5000 & 1.75 & 0.1525 & 0.5909 \\
\hline
\end{tabular}

Table 3 presents the concentration of heavy metals in well water at kwanar jaba (an area 250m from Tudun Murtala), Pb concentration ranges from 0.1429 to $0.6667 \mathrm{mg} / 1$ which is much lower as compared to the other samples from table 1 and 2 , so also the $\mathrm{Cd}$ concentration was observed to be lower but the $\mathrm{Cr}$ concentration increased and has higher abundance at all sites as compared to the first two tables. However $\mathrm{Zn}$ and Fe had very low value and even absent at some sites, this shows higher contamination of heavy metals at first site, mainly due to situation of industries in the sites and more industrial activities.

Table 4: Concentrations (mg/l) of metals in table water sold at Tudun Murtala

\begin{tabular}{lllllll}
\hline S/N & Table water & $\mathrm{Pb}$ & $\mathrm{Cd}$ & $\mathrm{Cr}$ & $\mathrm{Zn}$ & $\mathrm{Fe}$ \\
\hline 1 & G.T.W & 0.4762 & 0.7143 & 1.00 & 0.0960 & 0.3181 \\
2 & D.T.W & 0.3333 & 0.6429 & 0.75 & 0.1073 & 0.1818 \\
3 & L.T.W & 0.1905 & 1.00 & 1.50 & 0.1129 & 0.2727 \\
4 & DM.T.W & 0.1905 & 0.50 & 1.00 & 0.0621 & 0.3636 \\
5 & N.T.W & 0.2381 & 0.50 & 0.75 & 0.0282 & 0.50 \\
6 & AD.T.W & 0.3333 & 0.3571 & 0.75 & 0.0282 & 0.3181 \\
7 & Sa.T.W & 0.1429 & 0.4286 & 1.25 & 0.1186 & 0.1818 \\
8 & S.T.W & 0.5238 & 0.2143 & 0.50 & 0.0621 & 0.7727 \\
9 & Na.T.W & 0.2857 & 0.0714 & N.D & 0.0056 & N.D \\
10 & MM.T.W & 0.2381 & N.D & 0.75 & 0.1921 & N.D \\
\hline
\end{tabular}

Table 4 is the presentation of concentrations of metals in table water sold at Tudun Murtala, with Sa.T.W having the lowest $\mathrm{Pb}$ concentration $(0.1429 \mathrm{mg} / \mathrm{l})$ and S.T.W having the highest $\mathrm{Pb}$ concentrations $(0.5238 \mathrm{mg} / \mathrm{l})$. This range shows that all the table water are largely contaminated with $\mathrm{Pb}$. $\mathrm{Cd}$ was found to be absent in MM.T.W, but others have a concentration ranging from $0.0714-1.000 \mathrm{mg} / \mathrm{l}$, which indicates Cd contamination. Cr was also absent in Na.T.W but others have a range of $0.50-1.50 \mathrm{mg} / \mathrm{l}$, which is an unbearable $\mathrm{Cr}$ concentration. Zn was found to be within the permissible limit while Fe fluctuates with slight increase in permissible limit of some of the table waters.

\section{CONCLUSION}

The metal indices from water analysis obtained from Tudun Murtala and Kwanar jaba showed that the concentration of $\mathrm{Pb}, \mathrm{Cd}, \mathrm{Cr}$ and $\mathrm{Fe}$ in water samples were found to be above permissible limits while concentratiom of $\mathrm{Zn}$ was within the permissible limit set by WHO (2008). The elevated levels could be related to environmental pollution emanated from anthropogenic activities. Caution needs to be taken in the use of these water sources, as its contaminations are above bearable limits and it will be a threat to well living or predispose the users to heavy metal carcinogenesis. 


\section{REFERENCES}

Akan, J.C., Moses, E.A., ogungbuja, V.O. and Abah, J. (2007). Assessment of tannery industrial Effluent from Kano Metropolis, Kano state, Nigeria. Journal of Applied Sciences, 7: 2788-2793.

Canh, M. and Ahn, G. (2013). The relationship between heavy metals (Cd, Cr, Cu, Fe, Pb, Zn) levels and the size of meditteranean fish species, Environ. Pollution, 121: 129-136.

Chatterjee, S., Kundu, S., Sengupta, S. and Bhattacharyya, A. (2009). "Divergence to apoptosis from ROS induced cell cycle arrest: effect of cadmium,"Mutation Research, vol.663(1-2),pp.22- 31.

Cheney, K., Gumbiner, C., Benson, B. and Tenen- bein, M. (1995). "Survival after a severe iron poisoning treated with intermittent infusions of deferoxamine". J Toxicol Clin Toxicol, 33 (1): 61-6.

De Mattia, G. and Bravi, M. C. (2004). "Impairment of cell and plasma redox state in subjects professionally exposed to chromium." American Journal of Industrial Medicine, 46(2): 120-5.

Federal Register (2006). "Occupational Exposure to Hexavalent Chromium; Final Rule" Vol. 71, No. 39(Tuesday, February 28, 2006 / Rules and Regulations.

Fernandes, C., Fontainhas-Fernades, A., Cabral, D., Salgadp, M.A. (2008). Heavy metals in water, sediments and tissues of liza saliens from Esmonz-paramons lagoon, Portugal. Environ. Monit. Asses, 136: 267-275.

Fosmire, G. J. (1990). Zinc toxicity. American Journal of ClinicalNutrition, 51 (2): 225-7. PMID 2407097.

Gulson, B.L., Jameson, C.W., Mahaffey, K.R., Mizon, K.J., Korsch, M.J. and Vimpani, G. (1997). Pregnancy increases mobilization of lead from maternal skeleton. J Lab Clin Med, 30:51-62.

Hanson, M. L., Brundage, K. M., Schafer, R., Tou, J. C. and Barnett, J. B. (2010). "Prenatal cadmium exposure dysregulates sonic hedgehog and Wnt/ $\beta$-catenin signaling in the thymus resulting in altered thymocyte development," Toxicolog $y$ and Applied Pharmacology, vol. 242(2), Pp.136-145.

Hanson, M. L., Holaskova, I. and Elliott, M. (2012). “Prenatal cadmium exposure alters postnatal cell development and function," Toxicology and Applied Pharmacology, vol.261 (2), Pp.196-203.

Miller, Thomas, A. (2006). Modern surgical care physiologic foundations and clinical applications (3rd Ed.). Informa Healthcare. p. 34.

Nordberg, G.F., Nogawa, K., Nordberg, M., and Friberg, L. (2007). Cadmium, Handbook of the Toxicology of Metals, G.F. Nordberg, B.F. Fowler, M. Nordberg, and L. Friberg, Eds.,Pp. 445-486, Elsevier, Amsterdam, The Netherlands, 3rd edition.

Ogoyi, D.O., Mwita, C.J., Nguu, E.K. and Shiundu, P.M (2011). Determination of heavy metal content in waste, sediment and microalgae from lake Victoria, East Africa, The open Environment Engineering journal, 4: 156-161.

Schwartz, B.S., Lee, B.K., Lee, G.S., Stewart, W.F., Lee, S.S. and Hwang, K.Y. (2001). Associations of blood lead, dimercaptosuccinic acid-chelatable lead, and tibia lead with neurobehavioral test scores in South Korean lead workers. Am J Epidemiol; 153:453-64.

Singnh, S. and Mosley, L.M. (2003): Trace metals levels in drinking water on viti lerve. Fidi islands,pac.J.Nat. Sci. 21:31-34. 
U.S. Centers for Disease Control and Prevention. (2006). Atlanta, Georgia. "Safe Water System: A Low-Cost Technology for Safe Drinking Water." Fact Sheet, World Water Forum 4 Update.

WHO. (2011). Guidelines for drinking water quality fourth edition, Malta: Gruenbarge. ISBN: 9789241548151.

World health organisation. Guidelines for Drinking Water Quality ; World Health Organisation : Geneva, Switzerland, 2008. 